\title{
Interactive Effects of Drought and Grazing on Northern Great Plains Rangelands
}

\author{
R. K. Heitschmidt, ${ }^{1}$ K. D. Klement, ${ }^{2}$ and M. R. Haferkamp ${ }^{2}$ \\ Authors are ${ }^{1}$ Supervisory Rangeland Scientist and ${ }^{2}$ Rangeland Scientists, USDA Agricultural Research Service, Fort Keogh \\ Livestock and Range Research Laboratory, Miles City, MT 59301.
}

\begin{abstract}
Drought is common in rangeland environments and an understanding of its impacts on the structure and function of rangeland ecosystems is paramount for developing effective management strategies. This research was the second of a series of studies investigating the impacts of varying seasonal droughts on northern Great Plains rangelands. Research was conducted on native rangeland during the 1998 through 2001 growing seasons. Study plots were twelve $5 \times 10 \mathrm{~m}$ nonweighing lysimeters. An automated rainout shelter was used to establish drought conditions on 6 lysimeters during April, May, and June of 1998 and 1999. Single-day, flash grazing events were imposed at the beginning of May, June, and July. Grazing treatments were 1) graze during the 2 years of drought and the year after; 2) graze during the 2 years of drought and rest the year after; and 3) rest all years. Results showed that the intense spring drought reduced soil water content in the upper $30 \mathrm{~cm}$ of the soil profile and subsequently reduced total herbage production $20 \%$ to $40 \%$; cool-season perennial grasses were the primary contributor to the reduction and cool-season annual grasses were secondary. Periodic grazing during drought had minimal impact on herbage production, whereas impacts on nondrought plots ranged from moderate enhancement to moderate suppression, with effects varying depending on functional group. Results also showed that substantial recovery occurred during the 1st postdrought year, with near full recovery realized within 2 years.
\end{abstract}

\section{Resumen}

La sequía es común en los ambientes de pastizal y entender sus impactos en la estructura y función de estos ecosistemas es primordial para desarrollar estrategias efectivas de manejo. Esta investigación fue la segunda de una serie de estudios para investigar los impactos de variar sequías estacionales en los pastizales de las Grandes Planicies del norte. La investigación se condujo en un pastizal nativo durante las estaciones de crecimiento de 1998 al 2001. Las parcelas de estudio fueron 12 lisímetros que no se pesan de $5 \times 10 \mathrm{~m}$. Se uso un protector de lluvia automatizado para establecer las condicionas de sequía en 6 de los lisímetros durante Abril, Mayo y Junio de 1998 y 1999. A inicios de Mayo, Junio y Julio se impusieron eventos relámpago de apacentamiento de un solo día. Los tratamientos de apacentamiento fueron: 1) apacentamiento durante los dos años de sequía y el año posteriora ellos; 2) apacentamiento durante los 2 años de sequía y descanso en el año posterior a ellos y 3) descansar todos los años. Los resultados mostraron que la sequía intensa en primavera redujo el contenido de agua del suelo en los $30 \mathrm{~cm}$ superiores del perfil del suelo lo que redujo entre 20 y $40 \%$ la producción total de forraje, siendo los zacates perennes de estación fría los principales contribuyentes de la reducción y los zacates anuales de estación fría la segunda causa. El apacentamiento periódico durante la sequía tuvo un impacto mínimo en la producción de forraje mientras que los impactos en las parcelas sin sequía variaron de una mejoría moderada a una supresión moderada, con efectos variables, dependiendo del grupo funcional Los resultados también mostraron que ocurrió una recuperación substancial durante el primer año posterior a la sequía con una recuperación casi total en dos años.

Key Words: plant species composition, primary production, soil water

\section{INTRODUCTION}

Drought is a common event in rangelands and its effects on ecological processes, such as primary productivity, have been

Research was conducted under a cooperative agreement between USDA-ARS and the Montana Agricultural Experiment Station.

Mention of a proprietary product does not constitute a guarantee or warranty of the product by USDA, Montana Agricultural Experiment Station, or the authors and does not imply its approval to the exclusion of other products that may also be suitable. USDA-ARS Northern Plains Area is an equal opportunity/affirmative action employer and all agency services are available without discrimination.

Correspondence: Rod Heitschmidt, USDA Agricultural Research Service, 243 Fort Keogh Road, Fort Keogh Livestock and Range Research Laboratory, Miles City, MT 59301. Email: rod@larrl.ars.usda.gov

Manuscript received 10 July 2003; manuscript accepted 6 June 2004. studied and documented numerous times. The experimental designs for such studies generally have incorporated contrasts among a suite of pre- and postdrought response variables. However, recent technological developments in the construction and operational control of rainout shelters provide opportunities to conduct drought studies using more classical experimental designs (Owens 2003). The objective of this study was to evaluate the interactive effects of spring drought and grazing on northern Great Plains rangeland. Previous research using this same rainout shelter examined the interactive effects of an intense summer drought and grazing on aboveground biomass dynamics and primary productivity (Heitschmidt et al. 1999); root growth and seed bank dynamics (Hild et al. 2001); water yield, sediment production, and water quality (Emmerich and Heitschmidt 2002); and tiller dynamics (Eneboe et al. 2002). 


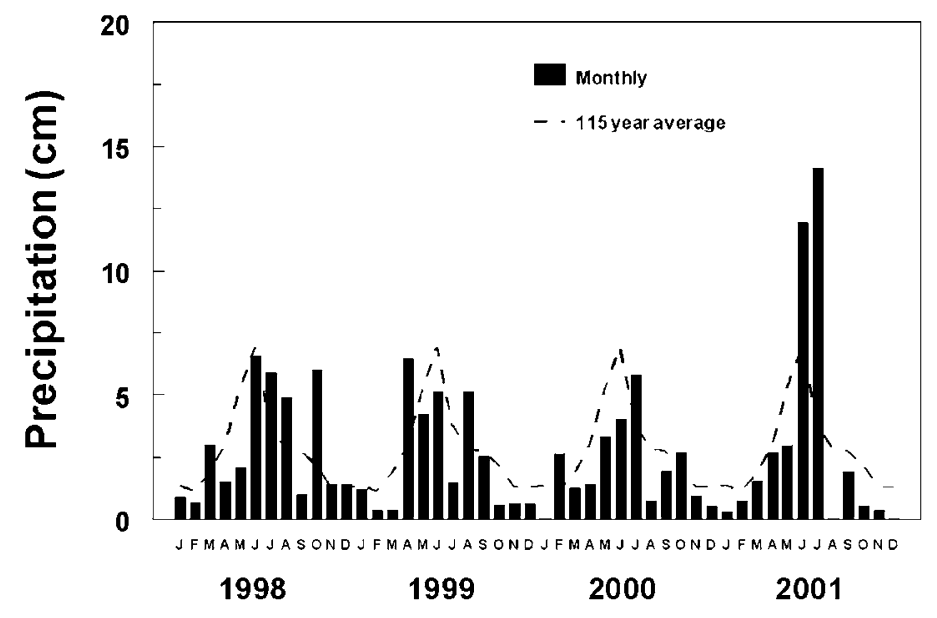

Figure 1. Monthly precipitation (in centimeters) from January 1998 through December 2001 and long-term (115 years) average at Miles City, Montana (NOAA 2001).

Our original underlying set of hypotheses driving this research centered on the idea that historical patterns of landscape utilization by large wild herbivores were likely quite different from current managed livestock grazing patterns. More specifically, we hypothesized that grazing patterns during and after drought would dramatically alter postdrought recovery patterns. However, our initial research (Heitschmidt and Haferkamp 2003) indicated that intense short-duration grazing bouts during and after intense summer drought had minimal impact on vegetation growth dynamics, net primary production, and plant species composition. We attributed this lack of impact largely to the evolutionary history of these ecosystems in that summer drought is a common event and does not serve as a notable ecological perturbation. We subsequently hypothesized that for drought to be a disruptive ecological event in the northern Great Plains, it would have to be either an intense spring drought or an extended drought that spanned across 2 or more growing seasons. The specific objective of this study was to examine the interactive effects of spring drought and grazing on aboveground biomass dynamics, net primary production, and plant species composition.

\section{MATERIALS AND METHODS}

\section{Study Area}

Research was conducted during the 1998 through 2001 growing seasons at the Fort Keogh Livestock and Range Research Laboratory located near Miles City, Montana (lat $46^{\circ} 22^{\prime} \mathrm{N}$, long $105^{\circ} 5^{\prime} \mathrm{W}$, elevation $725 \mathrm{~m}$ ). Regional topography ranges from rolling hills to broken badlands with small intersecting streams that seasonally drain into large permanent rivers meandering through broad, nearly level valleys. The potential natural vegetation on the 22500 -ha station is a grama-needlegrass-wheatgrass (Bouteloua-Stipa-Agropyron) mixed grass dominant (Küchler 1964). Long-term annual precipitation averages $34 \mathrm{~cm}$ with about $60 \%$ received during the 150-day, mid-April to mid-September growing season (Fig. 1). Average daily temperatures range from $-10^{\circ} \mathrm{C}$ in January to $24^{\circ} \mathrm{C}$ in July, with daily maximum temperatures occasionally exceeding $37^{\circ} \mathrm{C}$ during summer and daily minimums occasionally dipping below $-40^{\circ} \mathrm{C}$ during winter.

\section{Study Plots and Treatments}

Study plots were twelve $5-\times 10-\mathrm{m}$ nonweighing lysimeters constructed in 1992 on a gently sloping (4\%) clayey range site. Preconstruction soil analyses ensured soils in all lysimeters were Kobase silty clay loam, fine, montmorillonitic, frigid, Aridic Ustochrepts. Lysimeters were arranged perpendicularly to the slope along a $65-\mathrm{m}$ transect in 2 groups of 6 lysimeters each, with a $5-\mathrm{m}$ area between groups (Fig. 2). They were constructed by filling $12-\mathrm{cm}$-wide by $2-\mathrm{m}$-deep perimeter trenches, and juxtapositioned aboveground 12-cm-wide by $15-\mathrm{cm}$-tall wooden foundations, with urethane foam insulation. Each lysimeter was equipped with 2 soil water monitoring access tubes centrally positioned in the upper and lower half of each lysimeter. In addition, each lysimeter was equipped with

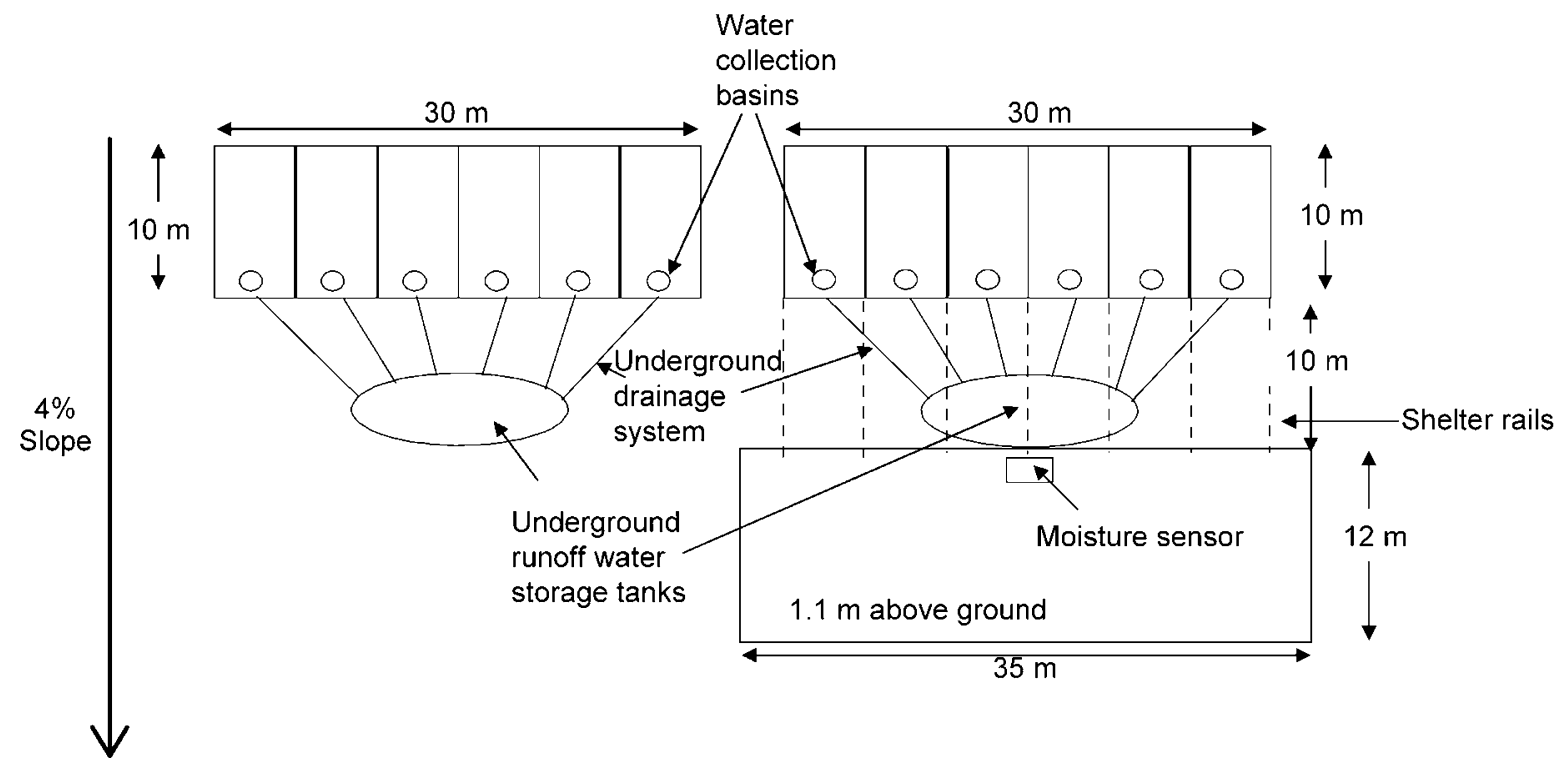

Figure 2. Study plot layout showing 6 nondrought lysimeters to left (i.e., west) of 6 drought treatment lysimeters and associated rainout shelter. 
a surface water runoff collection system consisting of a small (about $0.2 \mathrm{~m}^{2}$ ) concrete collection basin with underground plumbing for transporting water and sediment to individual fiberglass collection tanks. The study area had not been grazed by livestock since 1988 .

An automated rainout shelter was constructed to control the amount of precipitation received on 1 of the 2 sets of 6 lysimeters. The $12-\times 35$-m metal-framed roof was mounted on 15-cm-diameter plastic wheels atop 75 -cm-wide rails extending about $75 \mathrm{~cm}$ above the soil surface. Rails extended from top edge (i.e., upslope) to about $15 \mathrm{~m}$ below the bottom edge of the lysimeters. Rails were located directly over lysimeter borders. The shelter was equipped with a moisture-sensitive conductance plate that when wetted, activated a small electric motor and its associated drive system, which moved the shelter across the plots.

Randomly assigned, twice-replicated treatments were 1) graze during both years of the simulated drought and the year after and rest the fourth year, hereafter referred to as the graze-graze treatment $(\mathrm{GG})$; 2) graze during both years of the simulated drought and rest the 2 years thereafter, hereafter referred to as the graze-rest treatment (GR); and 3) rest all 4 years, hereafter referred to as the rest-rest treatment (RR). These same 3 treatments were randomly assigned and twice replicated in the nondrought set of lysimeters. All grazing events were relatively intense (i.e., postgrazing standing crops $<500 \mathrm{~kg} \cdot \mathrm{ha}^{-1}$ ) and equal among lysimeters (see Fig. 5).

Originally, the simulated drought was to be imposed only for 1 year (i.e., 1998). However, because of ambient spring drought conditions during the 1998 growing season (Fig. 1), we decided to impose the simulated drought conditions a second year (i.e., 1999). The planned simulated drought conditions both years were zero precipitation from 1 April to 30 June. However, because of rainout shelter malfunctions, the drought plots received $0.2 \mathrm{~cm}$ of ambient precipitation during this period in 1998 and $4.8 \mathrm{~cm}$ in 1999. This is in contrast to the nondrought plots receiving 10.3 and $15.9 \mathrm{~cm}$ during the same period in 1998 and 1999, respectively. Plots subjected to grazing were individually fenced and grazed intensively (i.e., to ground level) with 6 to 8 ewes for a few hours in early May, June, and July of 1998, 1999, and 2000.

\section{Sampling Procedures}

Precipitation was monitored on site using standard rain gauges. Soil water was estimated a minimum of once per month from April through October at depths of 15, 30,60, and $90 \mathrm{~cm}$ using a dielectric soil water probe (Troxler Sentry 200 AP).

Aboveground standing crops were estimated monthly, as well as immediately before and after each grazing event, from April through October, by clipping $10250-\mathrm{cm}^{2}$ circular quadrats per lysimeter. Five quadrats each were located randomly along two randomly located transects, one in the up-slope half of the lysimeter and the other in the down-slope half. Permanent records of quadrat locations were used to ensure no repeat clipping of any quadrat over the 4 years. Before harvesting standing crops, relative values of abundance were assigned to all species within each quadrat. Only the most abundant species were clipped individually, with most species combined into functionally similar groups. Species/species
Table 1. Analysis of variance models and associated degrees of freedom used in analyses of soil water (Models $A$ and $B$ ), herbage standing crop (Models $A$ and $B$ ), and aboveground net primary production (Models $C$ and D) data.

\begin{tabular}{lrrrr}
\hline & \multicolumn{4}{c}{ Model } \\
\cline { 2 - 5 } Source & A & B & C & D \\
\hline Drought (D) & 1 & 1 & 1 & 1 \\
Graze $(G)$ & 2 & 2 & 2 & 2 \\
$D \cdot G$ & 2 & 2 & 2 & 2 \\
Error $A^{1}$ & 6 & 6 & 6 & 6 \\
Year $(Y)$ & 3 & & 3 & - \\
Date $(D t)^{2}$ & 27 & 7 & - & - \\
$D \cdot Y$ & 3 & - & 3 & - \\
$G \cdot Y$ & 6 & - & 6 & - \\
$D \cdot G \cdot Y$ & 6 & - & 6 & - \\
$D \cdot D t$ & 27 & 7 & - & - \\
$G \cdot D t$ & 54 & 14 & - & - \\
$D \cdot G \cdot D t$ & 54 & 14 & - & - \\
Error $B^{3}$ & 180 & 36 & 18 & - \\
\hline B & & & &
\end{tabular}

${ }^{1}$ Replication within $(D \cdot G)$.

${ }^{2}$ Date within $(\mathrm{Y})$.

${ }^{3}$ Residual.

groups were western wheatgrass (Pascopyrum smithii Rydb. (Love)); needle-and-thread grass (Hesperostipa comata (Trin. \& Rupr.) Barkworth); warm-season perennial shortgrasses, which were a blue grama (Bouteloua gracilis (H. B. K.) Lag. ex Griffiths) and buffalograss (Buchloe dactyloides (Nutt.) Engelm.) mix; other warm-season perennial grasses, of which sand dropseed (Sporobolus cryptandrus (Torr.) A. Gray) and tumblegrass (Schedonnardus paniculatus (Nutt.) Trel.) were the dominant species; Bromus spp., which was principally Japanese brome (Bromus japonicus Thunb. ex Murr.) with a small amount of downy brome (Bromus tectorum L.); other coolseason perennial grasses, of which Sandberg's bluegrass ( $\mathrm{Po} a$ sandbergii Vasey) was dominant; other cool-season annual grasses, of which sixweeks fescue (Vulpia octoflora (Walt.) Rydb.) and little barley (Hordeum pusillum Nutt.) were dominant; forbs; plains pricklypear cactus (Opuntia polyacantha Haw.); and winterfat (Krascheninnikova lanata (Pursh.) A. D. J. Meeuse and Smith). Herbage was dried at $60^{\circ} \mathrm{C}$ for a minimum of 48 hours before weighing. Amounts of live (i.e., green) and dead (i.e., brown) tissue were then estimated by hand separation.

\section{Data Analyses}

Aboveground net primary production (ANPP) was estimated by functional group (i.e., cool-season perennial grasses, coolseason annual grasses, warm-season perennial grasses, and forbs) by summing increases in live biomass. Total production was estimated by summing functional group estimates.

Data were statistically analyzed using repeated measures analysis of variance procedures. Between-plot (i.e., lysimeter) effects were drought and grazing treatments. The error term for testing the effects of drought and grazing treatment and their associated interactions was plot within drought and grazing treatment. Years and/or dates and all associated 2- and 3-way 

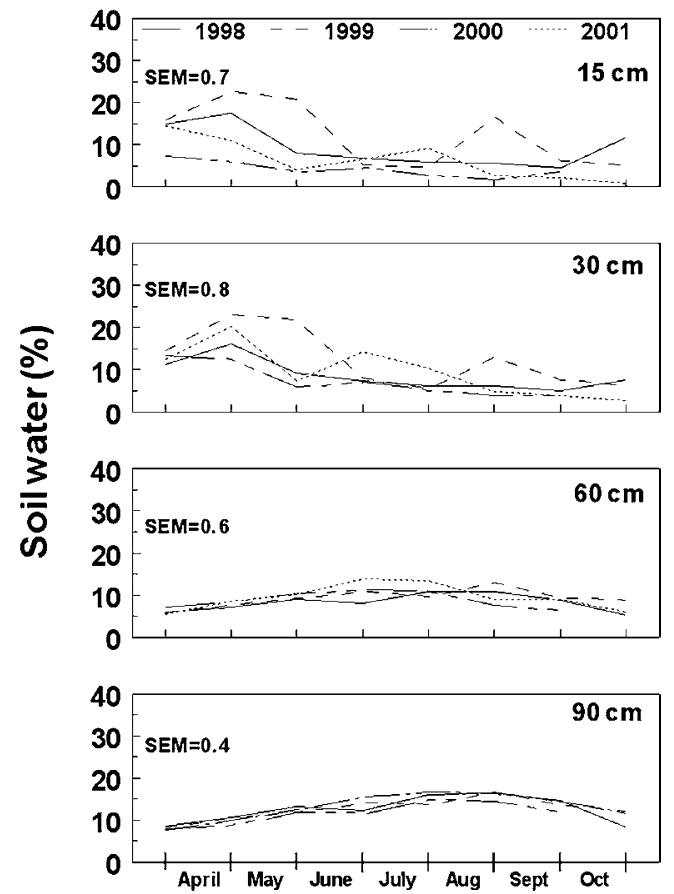

Figure 3. Extended growing season soil water content (\%) for 1998 through 2001 at 4 depths. Traces are averages for 2 drought and 3 grazing treatments.

interactions were analyzed as within-plot repeated measures and were tested using full model residuals.

The data analyses and subsequent interpretation of results were complex because they involved nearly 200 separate analyses of variance. Because our full models were 3- and 4factor repeated measure models (Table 1), significant interactions were common. As a means of assessing the relative importance of these many interactions, we routinely calculated the relative amount of model variation attributable to said interactions. Generally, if these interactions explained $<2 \%$ of total variation, we used smaller, more easily interpretable models in our analyses. Finally, because of the complex logistics associated with the conduct of this and most other field rainout shelter studies, construction costs necessitated we use a pseudoreplicated experimental design (Hurlbert 1984). Granted, this is unfortunate, but the alternative is often the elimination of important, cutting-edge research. We chose instead to conduct said research but impose conservative interpretive standards to guard against making Type I errors. Specifically, we used replications as our experimental units and a combination of conservative (i.e., least significant difference and Tukey Q) mean separation procedures.

\section{RESULTS}

\section{Precipitation and Soil Water}

Spring precipitation during 1998 was well below average, particularly during April and May (Fig. 1), whereas summer precipitation was above average until September. It was because of these deviations from normal that the decision was made to impose the drought treatment again during the spring of 1999. Precipitation during the spring and summer of 1999 was near normal, with substantial deviations during April and

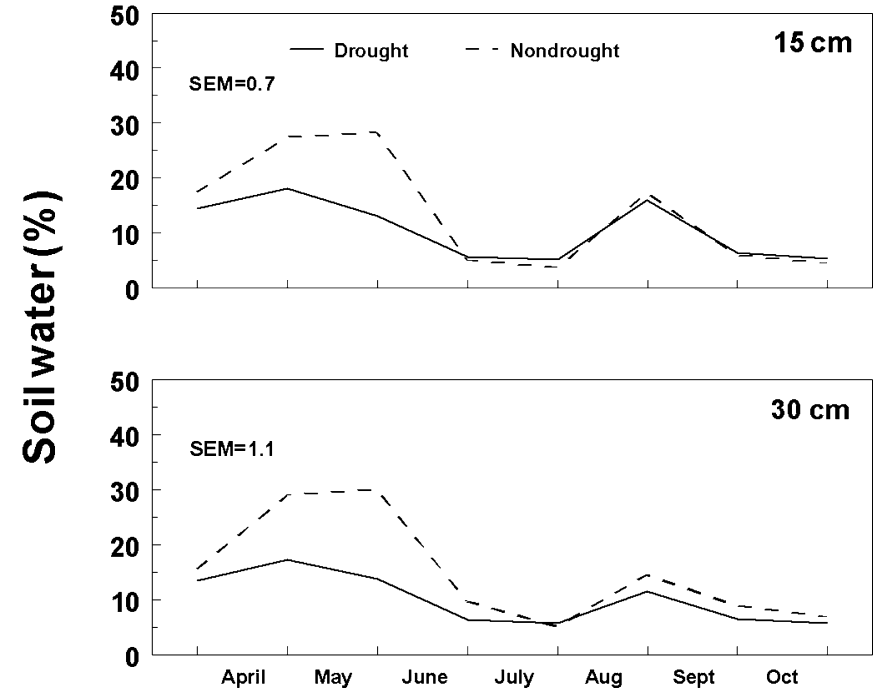

Figure 4. Soil water content (\%) for drought and nondrought plots in 1999 at $15-$ and 30 -cm depths.

July. Spring and summer precipitation during 2000 was generally below average except for July. Similarly, precipitation during the spring of 2001 was below average, whereas early summer precipitation was substantially above average.

Full model analyses (Table 1, Model A) of the soil water data by soil depth revealed no significant drought, grazing, or drought by grazing treatment interaction effects. However, both year and date effects were significant at all depths, as were numerous associated interaction effects. Subsequent withinyear analyses (Table 1, Model B) again revealed no significant drought, grazing, or drought by grazing treatment interaction effects at any depth within any year (Fig. 3) other than at the 15- and 30-cm depths in 1999 when spring soil water was less in the drought than nondrought plots (Fig. 4). These analyses, when combined with the 1998 spring precipitation data (Fig. 1), provide further support for our decision to impose the drought treatment again in 1999. As expected, date was a significant effect at all depths in all years in the reduced model analyses, and there were only 4 significant interaction effects, all of which were drought by date effects. Subsequent breakdown of these interactions revealed all were related to minor differences in rates of soil water dry-down, with 3 of the 4 occurring in the spring of 1999.

\section{Aboveground Biomass Dynamics}

As expected, full model analyses (Table 1, Model A) of live, dead, and total (live + dead) biomass by functional group (i.e., cool-season perennial grasses, cool-season annual grasses, warm-season perennial grasses, and forbs) resulted in an abundance of significant main and associated interaction effects. However, dynamic, interpretable, and biologically meaningful patterns emerged when full model analyses were coupled with within-years model analyses (Table 1, Model B) and visual assessments of patterns (Figs. 5 and 6).

Data presented in Figure 5 show that 1) grazing reduced standing crops as expected; 2) magnitudes of reductions were near equal across treatments; and 3) treatment differences 2 years after drought were minimal. Data presented in Figure 6 further 


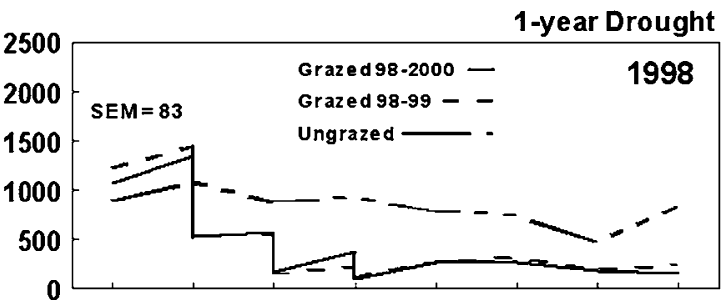

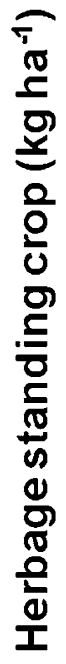

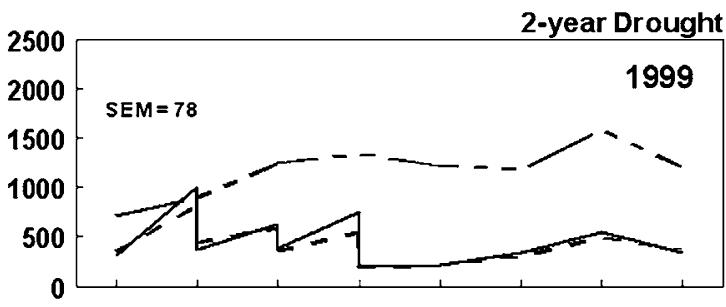

1-year Post-drought
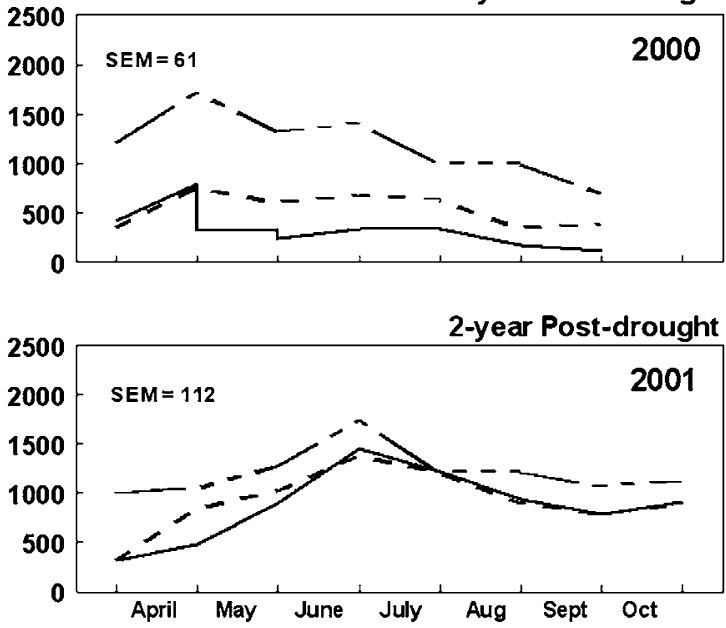

Figure 5. Total herbage standing crops $\left(\mathrm{kg} \cdot \mathrm{ha}^{-1}\right)$ for the 3 grazing treatments for 1998 through 2001 growing seasons. Traces are averages for 2 drought treatments.

clarify the effects of the 1999 and 2000 drought by revealing that total standing crops were essentially unaffected by the drought treatment, other than during 1999 (i.e., the second year of drought) and the first half of the 2000 growing season. Statistical analyses also revealed that the drought by grazing treatment interaction was significant in both 1999 and 2000. This interaction was because average standing crops in the drought plots were unaffected by grazing both years, whereas grazing reduced standing crops in the nondrought plots (Table 2).

The effects of the drought and grazing treatments on functional group standing crops are best reflected by their effects on ANPP estimates as presented in the following section. Still, based on pattern and number of significant effects evaluated across the numerous analyses of variance completed in the analyses of live, dead, and total standing crops by functional group, the following generalities were apparent. First, the impacts of both the drought and grazing treatments were greater on dead than live standing crop. This is because by definition, live precedes dead biomass, and therefore impacts on dead biomass reflect cumulative impacts on live biomass. Second, the relative impacts of both the drought and grazing treatments generally followed a pattern of cool-season perennial grasses $>$ annual

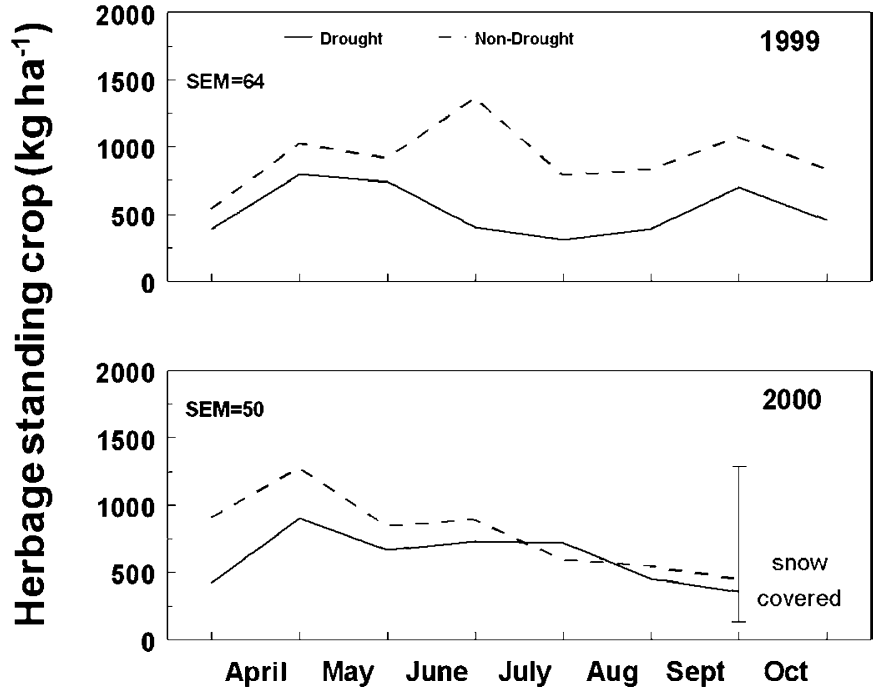

Figure 6. Total herbage standing crops $\left(\mathrm{kg} \cdot \mathrm{ha}^{-1}\right)$ for the drought and nondrought treatments for 1998 through 2001 growing seasons. Traces are averages of 3 grazing treatments.

grasses $>$ warm-season perennial grasses $>$ forbs. This is as expected considering that the imposed drought was a spring drought and grazing treatments were imposed from mid-spring to early summer. Both actions would be expected to have greater impact on cool-season than warm-season species and on perennials more so than annuals.

\section{Aboveground Net Primary Production}

Full model analyses (Table 1, Model C) of total ANPP revealed significant drought and year main effect and their interaction effect. Neither grazing treatment nor its interaction with drought or year were significant, although the drought by grazing treatment interaction did approach significance $(P=0.07)$. Because full model analyses by functional groups also revealed year as a consistently significant effect, withinyear analyses (Table 1, Model D) were used as the primary means for developing the interpretive summaries (Table 3 ).

Table 2. Mean standing crop estimates for 1999 and 2000 for drought by grazing treatment interactions (note that $G G$ was grazed in both years, GR only in 1999, and RR in neither year).

\begin{tabular}{|c|c|c|c|}
\hline \multirow[b]{2}{*}{ Year/drought treatment } & \multicolumn{3}{|c|}{ Grazing treatment $\left(\mathrm{kg} \cdot \mathrm{ha}^{-1}\right)$} \\
\hline & $\mathrm{GG}^{1}$ & GR & $\mathrm{RR}$ \\
\hline \multicolumn{4}{|l|}{1999} \\
\hline Drought & $369 a^{2}$ & $372 a$ & $825 a b$ \\
\hline Nondrought & $668 \mathrm{a}$ & $571 \mathrm{a}$ & $1547 b$ \\
\hline \multicolumn{4}{|l|}{2000} \\
\hline Drought & $310 a^{2}$ & $578 a$ & 931ab \\
\hline Nondrought & $402 a$ & $509 a$ & $1469 b$ \\
\hline
\end{tabular}


Table 3. $F$ values from analysis of variance for aboveground net primary productivity estimates for 1998 to 2001.

\begin{tabular}{|c|c|c|c|c|c|c|}
\hline \multirow[b]{2}{*}{ Source } & \multirow[b]{2}{*}{$d f$} & \multicolumn{5}{|c|}{ Functional group ${ }^{1}$} \\
\hline & & Total & CSPG & WSPG & ANGR & FORB \\
\hline \multicolumn{7}{|l|}{1998} \\
\hline Drought (D) & 1 & $25.6^{2}$ & $19.2^{2}$ & 2.5 & $<0.1$ & $<0.1$ \\
\hline Graze (G) & 2 & $17.3^{2}$ & $6.3^{3}$ & $<0.1$ & 2.7 & $<0.1$ \\
\hline$D \cdot G$ & 2 & $7.6^{3}$ & 4.1 & 0.3 & 1.7 & 1.0 \\
\hline \multicolumn{7}{|l|}{1999} \\
\hline $\mathrm{D}$ & 1 & $108.6^{2}$ & $67.2^{2}$ & 2.1 & $6.7^{3}$ & 5.2 \\
\hline G & 2 & $8.8^{3}$ & $14.2^{2}$ & 0.4 & 0.8 & $11.3^{2}$ \\
\hline$D \cdot G$ & 2 & 1.8 & $9.9^{3}$ & 2.9 & 1.5 & 2.7 \\
\hline \multicolumn{7}{|l|}{2000} \\
\hline D & 1 & 3.6 & 5.3 & 0.2 & 0.6 & 1.8 \\
\hline G & 2 & 0.1 & $6.5^{3}$ & $6.8^{3}$ & $7.7^{3}$ & 3.0 \\
\hline$D \cdot G$ & 2 & 2.4 & 1.4 & $5.1^{3}$ & $5.9^{3}$ & 1.4 \\
\hline \multicolumn{7}{|l|}{2001} \\
\hline$D$ & 1 & 1.0 & 0.6 & 2.6 & 0.2 & $9.1^{3}$ \\
\hline G & 2 & $<0.1$ & 0.6 & 0.6 & 1.7 & $12.6^{3}$ \\
\hline$D \cdot G$ & 2 & 0.8 & 1.9 & 3.7 & 0.7 & 1.3 \\
\hline
\end{tabular}

In 1998, the first year of the imposed drought, total ANPP was reduced $20 \%$ by drought (Fig. 7) and increased $33 \%$ by grazing (Fig. 8). However, the magnitude of these effects was not equal across treatments, as reflected by the presence of a significant drought by grazing treatment interaction (Table 3 ). Specifically, grazing increased total ANPP in the nondrought plots an average of $52 \%$ above the ungrazed plots with no impact in the drought plots (Table 4). This effect was largely the result of increased cool-season perennial grass production (Figs. 7 and 8), of which western wheatgrass was dominant. Moreover, these effects were limited to the main effects of drought and grazing treatment (Table 3), although the drought by grazing treatment interaction effect was approaching significance $(P=0.08)$. However, on the average, drought reduced cool-season perennial grass production $40 \%$, whereas grazing increased it $62 \%$.

By the second year of the study (i.e., 1999), total ANPP was $41 \%$ less in the drought than nondrought plots (Fig. 7). However, the effect of grazing per se was not apparent in that total ANPP was significantly less in the GR treatment than either the GG or RR treatments (Fig. 8), and there was no significant drought by grazing treatment interaction effect (Table 3). Again, the dominant functional group contributing to total ANPP was cool-season perennial grasses, and analyses of their ANPP revealed significant drought and grazing treatment effects accompanied by a significant interaction effect (Table 3). Analyses of this interaction showed that grazing reduced cool-season perennial grass production an average of $57 \%$ in the nondrought plots and $0 \%$ in the drought plots (Table 4). Drought also reduced annual grass production by $45 \%$ in 1999 (Fig. 7), whereas grazing increased forb production $250 \%$ (Fig. 8). The absence of soil water during spring, the period of rapid annual grass growth, explains why drought reduced annual grass production. The concomitant increase in forb production with grazing was largely the result of increased production of common dandelion (Taraxacum officinale Weber) in the grazed treatment plots.

The effects of the 1998 and 1999 droughts had minimal carryover effects into 2000 and 2001 (Fig. 7). Although grazing did not impact total ANPP in 2000, it did suppress cool-season perennial grass production (Fig. 8), and interaction with previous drought treatments plots (Table 3 ) tended to increase

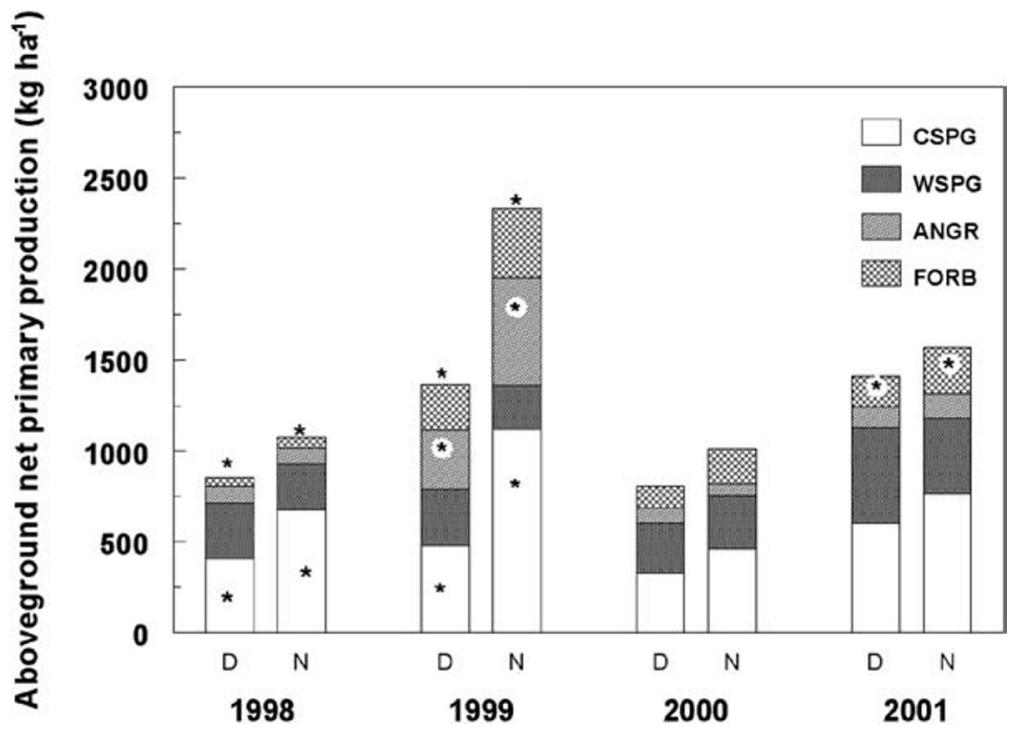

Figure 7. Aboveground net primary production estimates $\left(\mathrm{kg} \cdot \mathrm{ha}^{-1}\right)$ for warm-season perennial grasses (WSPG), cool-season perennial grasses (CSPG), annual grasses (ANGR), and forbs (FORB) in drought (D) and nondrought (N) treatments for 1998 through 2001. Asterisks within the same year $(*)$ indicate species group and/or totals that are significantly different at $P<0.05$. 


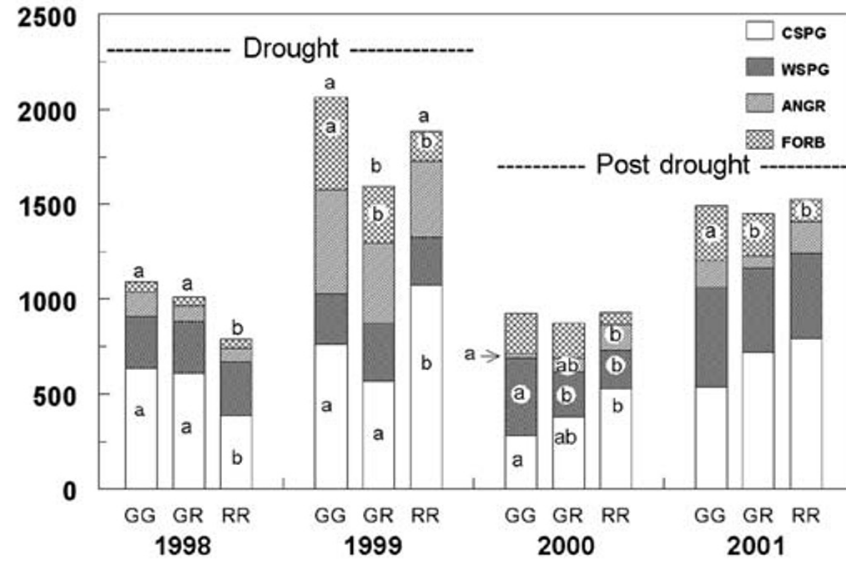

Figure 8. Aboveground net primary production estimates $\left(\mathrm{kg} \cdot \mathrm{ha}^{-1}\right)$ for warm-season perennial grasses (WSPG), cool-season perennial grasses (CSPG), annual grasses (ANGR), and forbs ([FORB] in the graze-graze, graze-rest, and rest-rest treatments for 1998 through 2001). Species group within year with same letters and totals within year with same letter above column are significantly different at $P<0.05$.

warm-season perennial grass production in the 1998-1999 nondrought plots and suppress annual grass production (Table 4). Again, a detailed review of the original plot data found no information linking these responses to any given species.

Essentially all the effects of the 1998-1999 drought and associated grazing treatments on ANPP were eliminated by 2001 (Table 3). The lone exception was that forb production was greater in the nondrought than drought plots (Fig. 7), and was greater in the 2000 grazed plots (i.e., GG) than the 2000 ungrazed plots (i.e., GR, RR) (Fig. 8). Again, common dandelion productivity explained most of these differences and was substantially greater in the drought and 2000 grazed plots.

\section{DISCUSSION AND CONCLUSIONS}

On the basis of the results of this study, we conclude that an intense spring drought in the northern Great Plains region: 1) reduces soil water content in the upper $30 \mathrm{~cm}$ of the soil profile (Figs. 3 and 4); and 2) reduces total herbage production in the range of $20 \%-40 \%$, with the decline attributed primarily to cool-season perennial grasses and secondarily to cool-season annual grasses (Fig. 7). We also conclude that 1) periodic flash grazing during drought will minimally impact herbage production, whereas effects will vary under nondrought conditions (Fig. 8, Table 4); and 2) postdrought recovery will be substantial the year after drought with or without intense flash grazing (Fig. 8), with near full recovery expected 2 years postdrought (Figs. 7 and 8 ).

The dramatic decline in soil water in the top $30 \mathrm{~cm}$ of the soil profile during the 1999 drought (Fig. 4) was not surprising. However, the absence of any measurable impact at the deeper depths (Fig. 3) was somewhat surprising but in agreement with the findings of others. For example, Reynolds et al. (1999) reported that above-average summer precipitation events in southern New Mexico did not recharge soil water at a $30-\mathrm{cm}$ depth in fine-textured sandy loam soils, whereas small recharge
Table 4. Estimates of aboveground net primary productivity (ANPP) $\left(\mathrm{kg} \cdot \mathrm{ha}^{-1}\right)$ for 1998-2000 for drought by grazing treatment interactions (note the GG was grazed all 3 years, GR in 1998 and 1999 only, and RR in no years).

\begin{tabular}{|c|c|c|c|}
\hline \multirow[b]{2}{*}{ Year/functional group/drought treatment } & \multicolumn{3}{|c|}{ Grazing Treatment $\left(\mathrm{kg} \cdot \mathrm{ha}^{-1}\right)$} \\
\hline & $\mathrm{GG}^{1}$ & GR & $\mathrm{RR}$ \\
\hline \multicolumn{4}{|l|}{1998 total } \\
\hline Drought & $875 a^{2}$ & $910 \mathrm{a}$ & $780 \mathrm{a}$ \\
\hline Nondrought & $1312 b$ & $1113 b$ & $800 \mathrm{a}$ \\
\hline \multicolumn{4}{|l|}{1999 Cool-season perennial grass } \\
\hline Drought & $387 a^{2}$ & $485 a$ & $576 a$ \\
\hline Nondrought & $1140 \mathrm{~b}$ & $633 b$ & $1570 \mathrm{c}$ \\
\hline \multicolumn{4}{|l|}{2000 Warm-season perennial grass } \\
\hline Drought & $299 a^{2}$ & $231 \mathrm{a}$ & $285 a$ \\
\hline Nondrought & $526 b$ & $235 a$ & $118 \mathrm{a}$ \\
\hline \multicolumn{4}{|l|}{2000 Annual grass } \\
\hline Drought & $20 a^{2}$ & $139 a$ & $97 a$ \\
\hline Nondrought & $14 a b$ & $11 b$ & $173 c$ \\
\hline
\end{tabular}

${ }^{1} \mathrm{GG}$ indicates graze during both years of the simulated drought and the year after, and rest the 4th year; GR, graze during both years of the simulated drought and rest the 2 years thereafter; and RR, rest all 4 years.

${ }^{2}$ Means in row or column with different letters are different at $P<0.05$.

was noted in adjacent coarser textured loamy sands, with the greatest recharge found in coarse sands. It follows then, that the near-static soil water dynamics we observed in this study below $30 \mathrm{~cm}$ was related to the capacity of these high-clay textured soils to buffer variations in soil water content at deeper depths (McAuliffe 2003).

The effects of the imposed spring drought on herbage standing crops and primary production (Fig. 7) are in agreement with previous findings showing that precipitation is the principal factor altering productivity of these rangelands (Whitman et al. 1943; Hurt 1951; Reed and Peterson 1961; Olson et al. 1985; Biondini and Manske 1996; Biondini et al. 1998; Heitschmidt et al. 1999). Similarly, results from this study (as well as those studies cited above) show that grazing consistently reduces herbage standing crops (Fig. 5), whereas its effects on ANPP can vary depending on the specific situation, as amply demonstrated in this study (Fig. 8). For example, in this study ANPP was greater in the grazed than nongrazed plots in 1998, but not so in either 1999 or 2000. This is because grazing increased coolseason perennial grass production in 1998 (Fig. 8) as a result of timely rainfall events of near $4 \mathrm{~cm}$ each in late May and early June and again in early July. In contrast, the absence of positive coolseason perennial grass responses to grazing in both 1999 and 2000 were likely related to the drier conditions of June and July 1999 and June 2000, as compared with 1998 (Fig. 1). Similarly, we hypothesize that the positive warm-season grass response observed in the grazed treatment in 2000 was related to the increased July 2000 precipitation as compared with 1999. Moreover, these results and associated explanations are supported by the findings of Eneboe et al. (2002) from earlier research conducted at this same site showing that flash grazing in June and July enhanced both the relative growth rates of tillers and rates of axillary tillering of western wheatgrass and blue- 
grama under nondrought conditions. Others have reported similar findings for dominant northern mixed grass prairie dominants including western wheatgrass (Sims et al. 1973), northern wheatgrass (Agropyron dasystachyum (Hook.) Scribn.) (Zhang and Romo 1994, 1995), annual brome grasses (Ganskopp and Bedell 1979; Haferkamp and Karl 1999), and bluegrama (Sims et al. 1973).

The impacts of this 2-year imposed spring drought regimen were considerably greater than we observed from the previously completed 1-year summer drought study (Heitschmidt et al. 1999). We believe the reasons for this are 2-fold. First, summer droughts in this region are common as reflected by long-term, monthly average precipitation values (Fig. 1). Thus, herbage growth is inherently slow during summer compared with spring when precipitation is most abundant. Second, precipitation during the entire 1994 growing season, the year of the imposed 1-year summer drought study, was well below normal, thereby limiting overall herbage production on the control or nondrought plots. This was reflected by an absence of any significant effect of the drought on soil water content.

It is also interesting to note that ANPP estimates were substantially greater during the 4 years of the summer drought study (i.e., 1993-1996) than in this study (i.e., 1998-2001), although plant species composition remained relatively constant. Averaged across years, total ANPP in the nondrought control plots averaged $2632 \mathrm{~kg} \mathrm{ha}^{-1}$ from 1993 through 1996 as compared with $1302 \mathrm{~kg} \mathrm{ha}^{-1}$ from 1998 through 2001 . We believe these differences are related largely to differences in annual precipitation regimens. For example, both spring (i.e., April to June) and total annual precipitation during the period 1993-1996 were near the long-term averages and 17\% and 8\% greater, respectively, than during the period from 1998 to 2001. In addition, late summer and fall precipitation was 30\% above average in 1992 before the start of the 1993 study, and 20\% below average in 1997 before the start of the 1998 study. The impacts of these differences were further reflected in growing season soil water estimates at the 15-, 30-, and 60-cm depths. Averaged across the nondrought control plots, soil water content during the 1993-1996 growing seasons averaged near $12 \%, 15 \%$, and $14 \%$ at the $15-, 30-$, and $60-\mathrm{cm}$ depths, respectively. This is in contrast to estimates near $9 \%, 10 \%$, and $9 \%$, respectively, during the 1998-2001 growing seasons.

Functional group responses across the two studies varied. Similar responses were that both the summer (Heitschmidt et al. 1999) and spring (Fig. 8) droughts 1) significantly reduced coolseason perennial grass production; 2) had minimal impact on forb production; and 3) realized near-full recovery 2 growing seasons after the simulated droughts. The reduced cool-season perennial grass production in both studies was as expected because the overwhelming dominant cool-season perennial grass species was western wheatgrass, which tends to have an extended growing period that spans from early spring to mid-summer in this region (Heitschmidt et al. 1977). Although forb production never varied in the summer drought study, it was significantly greater in the current study in the nondrought than drought plots and the grazed (GG) than ungrazed plots (GR + RR) 2 years postdrought (Figs. 7 and 8). However as discussed earlier, this was largely because of the presence of greater amounts of common dandelion, an opportunistic annual weed, in the grazed drought plots than the nondrought, ungrazed plots.
In contrast, both warm-season perennial and cool-season annual grass response patterns varied between the summer (Heitschmidt et al. 1999) and spring (Fig. 7) droughts. Differences were that 1) warm-season grass production increased with summer drought but was unaffected by spring drought; and 2) cool-season annual grass production was unaffected by summer drought and during the first year of the spring drought (i.e., 1998) but was reduced in the second year (i.e., 1999). As noted in the discussion of the results from the summer drought study (Heitschmidt et al. 1999), no biologically meaningful explanation could be offered about why warm-season perennial grass production increased with summer drought. The absence of a response to spring drought was because postdrought growing conditions favored warm-season perennial grass production. We believe the reason cool-season annual grass production was unaffected by the spring drought in year 1 (i.e., 1998) was because potential production was limited in both the drought and nondrought treatments by limited fall moisture in 1997. Haferkamp et al. (1995) and Karl et al. (1999) have shown that current year Japanese brome production is closely tied to previous fall precipitation. This understanding also helps explain why cool-season annual grass production varied considerably among years. For example, long-term average precipitation from October through December at this location is $4.8 \mathrm{~cm}$. Precipitation for this time period in 1997 through 2000 was $3.5,8.9,1.8$, and $5.8 \mathrm{~cm}$, respectively, all of which clearly are related to levels of annual grass production achieved the following year (Fig. 8).

An interesting comparison to the results of this study are those from several similar precipitation manipulation studies conducted in other grassland types, wherein it is repeatedly shown that timing of precipitation is a critical factor affecting the structure and function of rangeland ecosystems. For example, Svejcar et al. (2003) found that shifting peak precipitation from winter (i.e., October through April) to spring/ summer (i.e., May through July) in the sagebrush/bunchgrass shrub steppe vegetation of eastern Oregon, reduced both coolseason perennial and annual plant production and ground cover. Moreover, treatments did not impact the growth and persistence of the dominant shrub, Wyoming big sagebrush (Artemisia tridentata Nutt. var. wyomingensis Beetle \& Young). Similarly, Weltzin and McPherson (2003) examined the effects of varying precipitation regimens on the herbaceous component of the ecotone between oak woodland savanna and semidesert grassland in southeastern Arizona. From a combination of 50\% increases and decreases in summer and winter precipitation, they found that end-of-growing-season warm-season perennial grass standing crop was about 2-fold greater in wet than dry summer regimens. They also reported that aboveground standing crops of cool-season annual and perennial grasses, total belowground standing crops, and species richness and evenness were unaffected by varying precipitation regimens. Likewise, preliminary results from an ongoing 10-year rainfall manipulation study in the tallgrass prairie of eastern Kansas show temporal shifts in precipitation events that impact soil water dynamics, level of plant stress, and ultimately plant growth, productivity, and plant species composition (Fay et al. 2003).

The growth dynamics in the ungrazed, nondrought control plots of this study (data not shown) were similar to findings from other studies conducted on indigenous northern Great Plains rangelands (Lewis et al. 1971; Lauenroth et al. 1975; Lauenroth 
and Whitman 1977; Sims and Singh 1978a and 1978b; Dodd et al. 1982; Singh et al. 1983; Heitschmidt et al. 1995). Normally, peak standing crop in the northern Great Plains occurs between early June and mid-July, depending on plant species composition and pattern, and amount of precipitation. Our control plot data fit this pattern well, although variation is apparent when standing crops are averaged across drought and grazing treatments (Figs. 5 and 6). Likewise, ANPP estimates for this region generally range between 1600 and $3000 \mathrm{~kg} \mathrm{ha}^{-1}$, depending on site, year, and methodology (Singh et al. 1983; Heitschmidt et al. 1995; Heitschmidt et al. 1999), and as discussed earlier, the results of this study are generally low (Figs. 7 and 8). We attribute the lower-end estimates to the general drought conditions from 1997 through 2001.

\section{LITERATURE CITED}

BiondinI, M. E., AND L. MansKE. 1996. Grazing frequency and ecosystem processes in a northern mixed prairie. Ecological Applications 6:239-256.

Biondini, M. E., B. D. Patton, and P. E. Nyren. 1998. Grazing intensity and ecosystem processes in a northern mixed-grass prairie. USA. Ecological Applications 8:469-479.

Dodd, J. L., W. K. LauenRoth, and R. K. Heitschmidt. 1982. Effects of controlled $\mathrm{SO}_{2}$ exposure on net primary production and plant biomass dynamics. Journal of Range Management 35:572-579.

Emmerich, W. And R. K. Heitschmidt. 2002. Drought and grazing: II. Effects on quantity and quality of water. Journal of Range Management 55:229-234.

Eneboe, E. J., B. F. Sowell, R. K. Heitschmidt, M. G. Karl, and M. R. Haferkamp. 2002. Drought and grazing: IV. Blue grama and western wheatgrass. Journal of Range Management 55:197-203.

Fay, P. A., A. K. Knapp, J. M. Blair, J. D. Carlisle, B. T. Danner, and J. K. McCarron. 2003. Rainfall timing, soil moisture dynamics, and plant responses in a mesic tallgrass prairie ecosystem. In: J. F. Weltzin and G. R. McPherson [eds.]. Changing precipitation regimes and terrestrial ecosystems: A North American perspective. Tucson, AZ: University of Arizona Press. p 147-163.

Ganskopp, D. C., AND T. E. Bedell. 1979. Cheatgrass and its relationship to climate: A review. Corvallis, OR: Oregon Agricultural Experiment Station. Special Report 562.

Haferkamp, M. R., And M. G. Karl. 1999. Clipping effects on growth dynamics of Japanese brome. Journal of Range Management 52:339-345.

Haferkamp, M. R., M. D. MacNeil, and M. G. Karl. 1995. Induction of secondary dormancy in Japanese brome (Bromus japonicus), In: Neil E. West [ed.]. Rangelands in a sustainable biosphere. Denver, CO: Society of Range Management. p 199-200.

Heitschmidt, R. K., E. E. Grings, M. R. Haferkamp, and M. G. Karl. 1995. Herbage dynamics on 2 Northern Great Plains range sites. Journal of Range Management 48:211-217.

Heitschmidt, R. K., And M. R. Haferkamp. 2003. Ecological consequences of drought and grazing on grasslands of the Northern Great Plains. In: J. F. Weltzin and G. R. McPherson [eds.]. Changing precipitation regimes and terrestrial ecosystems: A North American perspective. Tucson, AZ: University of Arizona Press. p 107-126.

Heitschmidt, R. K., W. K. Lauenroth, and J. L. Dodd. 1977. Effects of controlled levels of sulphur dioxide on western wheatgrass in a southeastern Montana grassland. Journal of Applied Ecology 14:859-868.

Hild, A. L., M. G. Karl, M. R. Haferkamp, and R. K. Heitschmidt. 2001. Drought and grazing: III: Root dynamics and germinable seed bank. Journal of Range Management 54:292-298.

Heitschmidt, R. K., M. R. Haferkamp, M. G. Karl, and A. L. Hild. 1999. Drought and grazing: I. Effects on quantity of forage produced. Journal of Range Management 52:440-446.

Hurlbert, S. H. 1984. Pseudoreplication and the design of ecological field experiments. Ecological Monographs 54:187-211.

HURT, L. C. 1951. Managing northern Great Plains cattle ranges to minimize the effects of drought. Washington, DC: USDA Circ. 865.
Karl, M. G., R. K. Heitschmidt, and M. R. Haferkamp. 1999. Vegetation biomass dynamics and patterns of sexual reproduction in a Northern mixed-grass prairie. American Midland Naturalist 141:227-237.

KuCHLER, A. W. 1964. Potential natural vegetation of the coterminous United States. New York, NY: American Geographical Society. Special Publication 36.

Lauenroth, W. K., J. L. Dodd, R. K. Heitschmidt, and R. G. Woodmansee. 1975. Biomass dynamics and primary production in mixed prairie grasslands in southeastern Montana: baseline data for air pollution studies, In: Proceedings of the Fort Union Coal Field Symposium. April 25-26, 1975; Billings, MT: Montana Academy of Science. p 559-578.

Lauenroth, W. K., And W. C. Whitman. 1977. Dynamics of dry matter production in a mixed-grass prairie in western North Dakota. Oecologia 27:339-351.

Lewis, J. K., J. L. Dodd, H. L. Hutcheson, and C. L. Hanson. 1971. Abiotic and herbage dynamics studies on the Cottonwood Site, 1970. Ft. Collins, C0: Colorado State University. US/IBP Grassland Biome Technical Report 111.

McAuLIFFE, J. R. 2003. The interface between precipitation and vegetation: the importance of soils in arid and semiarid environments. In: J. F. Weltzin and G. R. McPherson [eds.]. Changing precipitation regimes and terrestrial ecosystems: A North American perspective. Tucson, AZ: University of Arizona Press. p 9-27.

National Oceanic and Atmospheric Administration. 2001. Climatological Data Annual Summary Montana. Asheville, NC: US Department of Commerce. v. 104 No. 13 p 10-11.

Olson, K. C., R. S. White, and B. W. Sindelar. 1985. Responses of vegetation of the northern great plains to precipitation amount and grazing intensity. Journal of Range Management 38:357-361.

OWENS, M. K. 2003. Approaches and techniques of rainfall manipulation. In: J. F. Weltzin and G. R. McPherson [eds.]. Changing precipitation regimes and terrestrial ecosystems: A North American perspective. Tucson, AZ: University of Arizona Press. p 72-89.

Reed, M. J., and R. A. Peterson. 1961. Vegetation, soils, and cattle responses to grazing on northern Great Plains range. In: USDA Forest Service Technical Bulletin 1252. Washington, DC: US Printing Office, USDA.

Reynolds, J. F., R. A. Virginia, P. R. Kemp, A. G. De Soyza, and D. C. Tremmel. 1999. Impact of drought on desert shrubs: effects of seasonality and degree of resource island development. Ecological Monographs 69:69-106.

Sims, P. L., R. K. Lang'at, and D. N. Hyder. 1973. Developmental morphology of blue grama and sand bluestem. Journal of Range Management 26: 340-344.

Sims, P. L., AND J. S. Singh. 1978a. The structure and function of ten western North American grasslands II. Intra-seasonal dynamics in primary producer compartments. Journal of Ecology 66:547-572.

Sims, P. L., AND J. S. Singh. 1978b. The structure and function of ten western North American grasslands. III. Net primary production, turnover and efficiencies of energy capture and water use. Journal of Ecology 66:573-597.

Singh, J. S., W. K. Lauenroth, R. K. Heitschmidt, and J. L. Dodd. 1983. Structural and functional attributes of the vegetation of northern mixed prairie of North America. Botanical Reviews 49:117-149.

Svejcar, T., J. Bates, R. AngelL, And R. Millek. 2003. The influence of precipitation timing on the sagebrush steppe ecosystem. In: J. F. Weltzin and G. R. McPherson [eds.]. Changing precipitation regimes and terrestrial ecosystems: A North American perspective. Tucson, AZ: University of Arizona Press. p 90-106.

Weltzin, J. F., and G. R. McPherson. 2003. Response of Southwestern Oak Savannas to potential future precipitation regimes. In: J. F. Weltzin and G. R. McPherson [eds.]. Changing precipitation regimes and terrestrial ecosystems: A North American perspective. Tucson, AZ: University of Arizona Press. p 127-146.

Whitman, W., H. C. Hanson, and P. A. Peterson. 1943. Relation of drought and grazing to North Dakota rangelands. Fargo, ND: North Dakota Agricultural Experiment Station Bulletin 320.

Zhang, J., AND J. T. Romo. 1994. Defoliation of a northern wheatgrass community: above- and belowground phytomass productivity. Journal of Range Management 47:279-284.

Zhang, J., and J. T. Romo. 1995. Impacts of defoliation on tiller production and survival in northern wheatgrass. Journal of Range Management 48: $115-120$. 